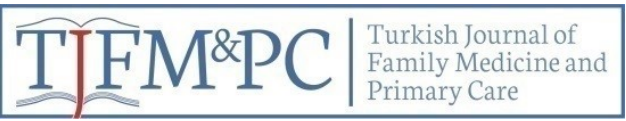

Original Article/Özgün Araştırma

\title{
Evaluation of the Approaches of Women Registered to a Family Medicine Unit in Ankara Regarding Having Cervical Cancer Screening Tests
}

\author{
Ankara'da Bir Aile Hekimliği Birimine Kayıtlı Kadınların Serviks Kanseri Taramalarına \\ İlişkin Yaklaşımlarının Değerlendirilmesi \\ Hatice Küçükceran $^{* 1}$, Ezgi Ăgadayl ${ }^{* 2}$, Hayriye Şentürk ${ }^{* 3}$
}

\begin{abstract}
Aim: The aim of this study is to evaluate the approaches of women between 30-65 years regarding having cervical cancer screening tests and to determine the obstacles against screening. Methods: In this study, a total of 313 participants aged 30-65 years who were registered to the Family Medicine Unit No:8 of Akyurt, Ankara province, were interviewed in June 2018. A questionnaire in which socio-demographic data was collected and participants' level of knowledge about cervical cancer screening was evaluated, is conducted. After determining the level of knowledge of the participants, standard information were given about cervical cancer screening. After informing, the participants were invited to the Family Health Center (FHC) for screening purposes and the reasons for rejection of those whore fused to take the screening were noted. All analyzes were performed using SPSS program. Results: There were 511 women in the 30-65 age range, registered to the unit. Questionnaire was not applied to 71 women who had previously been tested for HPV DNA in the system. The meanage of the 313 women eligible to participate in the survey was $44.8 \pm 10.2$. The majority of the participants $(66.1 \%)$ were primary school graduates. Of 313 participants, $64.2 \%$ knew that screening was performed at FHC. While $70.3 \%$ people agreed to have the screening, $29.7 \%$ denied. When there asons for denial were asked, it was learned that $52.6 \%$ were afraid of gynecological examination, $35.4 \%$ were already followed by gynecologists and obstetricians and did not want to perform the screening in a FHC and 11.8 found cervical cancer screening unnecessary. Conclusion: The rate of women who had cervical cancer screening before the study was found to be very low, and after the necessary information was given, the rate of those who wanted to have the test at FHC increased. In addition, we think that when Gynecology and Obstetrics Policlinics and Family Health Center work integratedly, cancer screening rates will rise.
\end{abstract}

KeyWords: Cervical Cancer, HPV test, cancer screening, Family Health Center

ÖZET:

Amaç: Çalışmanın amacı, 30-65 yaş arası kadınların serviks kanseri tarama testlerini yaptırmaya ilişkin yaklaşımlarını değerlendirmek ve taramayı yaptırmaya karşı olan engelleri tespit etmektir. Yöntem: Çalışmamıza Haziran 2018 tarihinde, Ankara İli Akyurt 8 No'lu Aile Hekimliği Birimine kayıtlı 30-65 yaş arası 313 kişi dahil edildi. Katılımcılara sosyo-demografik verilerin toplandığı ve katılımcıların servikal kanser taraması konusunda bilgi düzeyinin değerlendirildiği anket uygulandı. Katılımcıların bilgi düzeyi belirlendikten sonra kişilere serviks kanseri taraması ile ilgili standart bilgiler verildi. Bilgilendirme sonrası katılımcılar Aile Sağlı̆̆ Merkezine (ASM) tarama amacıyla davet edildi ve taramayı yaptırmayı kabul etmeyenlerin ret sebepleri not edildi. Tüm analizler SPSS programı kullanılarak yapıldı. Bulgular: Birime kayıtlı 30-65 yaş aralığında 511 kadın bulunmaktaydı. Sistemde daha önce HPV testi yaptırdığ tespit edilen 71 kadına anket uygulanmadı. Ankete katılmaya uygun olan 313 kadının yaş ortalaması 44,8 10,2 idi. Katılımcıların büyük çoğunluğu (\%66,1) ilköğretim mezunu idi. Katılımcıların \%64,2'si ASM'de taramanın yapıldığını biliyordu. Katılımcıların \%70,3'ü taramayı yaptırmayı kabul ederken, $\% 29,7$ 'si yaptırmak istemedi. Tarama yaptırmak istemeyenlere sebepleri sorulduğunda \%52,6's1 jinekolojik muayeneden çekindiğini, \%35,4'ü kadın hastalıkları ve doğum uzmanı tarafından takip edildiğini ve ASM'de yaptırmak istemediğini, \%11,8'i ise rahim ağzı kanseri taramasını gereksiz bulduğunu ifade etti. Sonuç: Çalışma öncesi servikal kanser taraması yaptıran kadınların oranı çok düşük bulunmuş olup, gerekli bilgilendirmeler yapıldıktan sonra testi ASM'de yaptırmak isteyenlerin oranı yükselmiştir. Ayrıca, Kadın Doğum Poliklinikleri ile Aile Sağlığı Merkezleri, kanser taramaları konusunda entegre bir şekilde çalışmaya başlarsa taramalar daha düzenli yapılabilir ve oranlar artabilir.

Anahtar Kelimeler: Serviks kanseri, HPV testi, Kanser tarama, Aile Sağlı̆̆1 Merkezi

Received Date:,26.11.2019 Accepted Date: 17.04.2020

*1 Necmettin Erbakan Üniversitesi Meram Tıp Fakültesi Aile Hekimliği Anabilim Dalı

*2 Cumhuriyet Üniversitesi Tıp Fakültesi Tıp Eğitimi Anabilim Dalı

*33 Konya Meram İlçe Sağlık Müdürlüğü

Address for Correspondence / Yazışma Adresi Hocacihan Mah. Abdulhamidhan Cad. No:3 Selçuklu /KONYA

E-mail:drhaticeran@gmail.com

Küçükeren H., Ağadayı E., Şentürk H. Evaluation of the Approaches of Women Registered to a Family Medicine Unit in Ankara Regarding Having Cervical Cancer Screening Tests TJFMPC, 2020;14 (2): 259-266.

DOI: $10.21763 /$ tjfmpc. 650940

Küçükceran et al., TJFMPC www.tjfmpc.gen.tr 2020; 14(2) 


\section{GiRiș}

Uluslararası Kanser Araştırmaları Ajansı (IARC)'nın bir projesi olan GLOBOCAN 2018, 185 ülkede 36 kanser için dünya çapında insidans ve mortalite tahminleri kullanarak dünya çapında küresel kanser yükü hakkında bir durum raporu sunmaktadır. GLOBOCAN 2018 verilerine göre serviks kanseri Dünyada 4. en sık görülen kadın kanseridir. ${ }^{1,2}$ Türkiye'de ise kadınlarda serviks kanseri 9. sırayı almıştır. ${ }^{3}$

Sağlığı geliştirme ve hastalıkları önleyici hizmetleri sunma aile hekimliğinin temel ilkelerindendir. ${ }^{4}$ Türkiye'de 2010 yılında geçilen aile hekimliği uygulamaları kanser taramalarında büyük kolaylık sağlamıştır. Aile hekimleri kanser tarama programının topluma anlatılmasında ve katılımın artırılmasında, taramaya katılacak olan hedef nüfusun davet edilmesinde, tarama sonuçlarının kişiye iletilmesinde anahtar role sahiptir.

Servikal kanser; preinvazif lezyonun varlığı, taramasının kolay olması, erken teşhis edildiğinde de \%100 tedavi edilebilir olması sebebiyle tarama için uygun bir kanser türüdür. Servikal kanserlerin \%99'u Human papilloma virüsüne (HPV) bağlıdır ve bu sebeple etyopatogenezi aydınlatılmış ve önlenebilen tek kanserdir. ${ }^{5,6}$ Servikal kansere sebep olan HPV genotipleri ise $\% 70$ oranla HPV-16 ve HPV-18' dir.

Servikal kanser taramalarının geleneksel sitolojinin yanı sıra öncelikli olarak HPV DNA testleri ile yapılması, Aralık 2012'de karara bağlanmıştır. Yenilenen ulusal kanser tarama standartlarına göre 30-65 yaş grubundaki her kadının 5 yılda bir HPV testi ile taranması, pozitif çıkan olguların smear ile tekrar değerlendirilmesi planlanmıştır. ${ }^{5}$ Bu uygulama tarama ve tanı koyma açısından büyük kolaylık sağlayarak geçmiş yıllara kıyasla rahim ağzı kanseri tarama oranlarında kabaca altı kat artışa yol açmıştır. ${ }^{7}$ Rahim ağzı kanseri tarama programını uygulayan ilk İslam ülkesi Türkiye'dir.7 Ayrıca Temmuz 2019'dan itibaren Hollanda ve Türkiye, ulusal HPV tabanlı rahim ağzı kanseri taraması yapılan Avrupa ülkeleri olarak listede ilk sıraya yerleşmiştir. İtalya, İsveç ve Finlandiya ise bazı bölgelerde HPV tabanlı taramayı uygulamaya geçirmiştir. ${ }^{8}$
$\mathrm{Bu}$ çalışmadaki amacımız taramada hedef olan 30-65 yaş arası kadınların serviks kanseri tarama testlerini yaptırmaya ilişkin bilgi, tutum ve davranışlarını değerlendirmek ve taramayı yaptırmaya karşı olan engelleri tespit etmektir. $\mathrm{Bu}$ çalışmadan elde edilen veriler birinci basamak sağlık kuruluşlarında serviks kanseri tarama oranlarını artırılmasına yardımcı olabilir.

\section{YÖNTEM}

Araştırma tanımlayıcı özellikte, prospektif bir çalışmaydı. Çalışmamız Ankara ili Akyurt 8 No'lu Aile Hekimliği Birimine kayıtlı 30-65 yaş arası kadınlar üzerinde uygulandı. Sağlık Bakanlığı Kanserle Savaş Dairesi tarafından yayınlanan 2009/78 say1l genelgede serviks kanseri ulusal tarama standartları belirlenmiştir. $\mathrm{Bu}$ genelge ile 30-65 yaş arası kadınların taranması planlanmaktadır. ${ }^{5} \mathrm{Bu}$ sebeple çalışmamızı 30-65 yaş arası kadınlar üzerinde planladık.

1 Haziran 2018 tarihinde Akyurt 8 No'lu Aile Hekimliği Birimine kayıtlı 30-65 yaş aralığındaki kadın nüfusun 511 kişi olduğu belirlendi. Son 5 yıl içerisinde serviks kanseri taraması yaptırdığı tespit edilen 71 kişiye anket uygulanmadı fakat bu sayı not edildi. Ayrıca halen veya geçmişte cinsel aktif olmayan 34 kişi ve total histerektomi ameliyatı öyküsü olan 6 kişi, gebe olan 12 kişi, ankete katılmayı kabul etmeyen 23 kişi ve telefonla ulaşılamayan 52 kişi çalışma dışı bırakıldı. Geriye kalan 313 kişiye 1 Haziran 2018 - 1 Temmuz 2018 tarihleri arasında mevcut anketimiz telefonda görüşülerek uygulandı. Anket öncesinde araştırma hakkında bilgi verilen katılımcılardan sözlü onam alındı.

Literatür taraması sonucu araştırmacılar tarafından hazırlanan anket formumuz iki bölümden oluşmaktadır. İlk bölümde kadınlara sosyodemografik özellikleri, serviks kanseri ve tarama testleri ile ilgili bilgi düzeylerini ölçen sorular soruldu. Katılımcının bilgi düzeyi belirlendikten sonra Sağlık Bakanlığının resmi sitesinde yer alan ve halka yönelik geliştirilen 'Ulusal HPV-smear tarama testi nasıl yapılır?' başlıklı metinden faydalanılarak katılımcilar telefonla bilgilendirildi. Telefon görüşmesi mesai saatleri dışında saat 12:00-13:00 arasında yapıldı, yaklaşık beş dakika sürdü. HPV ve Pap-smear testi nedir, neden, nasıl ve ne zaman yapılır alt başlıklarında 15 cümleden oluşan standart bilgiler hastaya okundu. ${ }^{5}$ 
Anketin ikinci bölümünde, bilgilendirme sonrası hasta HPV ve Pap-smear testini yaptırmak amaciyla Aile Sağlığı Merkezine (ASM) davet edildi. Testleri yaptırmayı kabul ettiğini ifade eden katılımcılar için en kısa zamanda Aile Sağlığı Merkezine geleceği bilgisi not edildi. Testleri yaptırmayı reddeden katılımciların ise ret sebepleri kaydedildi.

Çalışma için gerekli etik kurul onay, E-181827 sayı ile Sağlık Bilimleri Üniversitesi Ankara Numune Eğitim Araştırma Hastanesi Klinik Çalışmalar Etik Kurulundan alındı. Ayrıca çalışmaya başlamadan önce Türkiye Halk Sağlığ Kurumundan gerekli izinler alındı.

Verilerin istatistiksel analizinde Statistical Package for Social Sciences (SPSS) programı kullanıldı. Sayısal değişkenlerin normallik analizi Shapiro-Wilk testi ile yapıldı. Kategorik değişkenlerin karşılaştırmaları Ki-kare testi ile değerlendirildi. Parametrik olmayan sayısal verilerin kategorik verilerle karşılaştırılmasında Mann-Whitney U testi kullanıldı. Uygulanan istatistiksel testlerden elde edilen sonuçlar \%95 güvenlik aralığı ile $\mathrm{p}$ değerinin 0,05 'in altında olması anlamlı olarak kabul edildi.

\section{BULGULAR}

Çalışmanın yapıldığı ASM birimine kayıtlı 30-65 yaş aralığında 511 kadın bulunmaktaydı. 71 $(\% 13,89)$ kişinin sistemde daha önce HPV testi yaptırdığı tespit edildi ve bu kişiler çalışma dışı bırakıld1. Daha önce HPV testi yaptırmayan ve çalışmamıza katılmayı kabul eden 313 kişiye anket uygulandı. Katılımcıların yaş ortalaması $44,8 \pm 10,2$ idi. Katılımcıların büyük çoğunluğu (\%66,1; $\mathrm{n}=207)$ ilköğretim mezunu idi. Sosyo-demografik özellikleri Tablo 1'de gösterilmektedir.

Katılımcıların \%99'u rahim ağzı kanserini, \%84,7'si Pap-smear testini, \%52,1'i ise HPV testini daha önce duyduğunu ifade etti. Serviks kanseri taramasının hangi merkezlerde yapılıyor olduğunu sorduğumuzda; \%80,2'si Kadın Hastalıkları ve Doğum Kliniğinde, \%64,2'si Aile Sağlı̆̆ Merkezlerinde, \%63,9’u KETEM (Kanser Erken Teşhis Tarama ve Eğitim Merkezi)'de yapıldığını bildiğini söyledi. Katılımcıların rahim ağzı kanseri ile HPV ve smear testi hakkındaki bilgi düzeyleri Tablo 2'de gösterilmektedir.

\begin{tabular}{|l|l|c|c|}
\hline \multicolumn{2}{|l|}{ Tablo 1. Katılımcıların sosyo-demografik özellikleri } \\
\hline \multirow{4}{*}{ Yaş } & $30-39$ yaş & 117 & Yäzde(\%) \\
\hline \multirow{4}{*}{ Öğrenim Durumu } & $40-49$ yaş & 98 & 37,4 \\
& $50-65$ yaş & 98 & 31,3 \\
& Okur-yazar değil & 16 & 31,3 \\
& İlköğretim & 207 & 5,1 \\
& Lise & 81 & 66,1 \\
& Üniversite & 9 & 25,9 \\
\hline \multirow{3}{*}{ Medeni Hali } & Evli & 289 & 2,9 \\
\hline
\end{tabular}




\begin{tabular}{|l|c|c|}
\hline \multicolumn{2}{|l|}{ Tablo 2. Katılımcıların rahim ağzı kanseri ile HPV ve smear testi hakkındaki bilgi düzeyleri } \\
\hline & Evet & Hayır \\
\hline Daha önce rahim ağzı kanserini duydunuz mu? & $310(\% 99,0)$ & $3(\% 1,0)$ \\
\hline Rahim ağzı kanserine erken tanı koymak içın kadınlara tarama yapılldı̆ını biliyor musunuz? & $277(\% 88,5)$ & $36(\% 11,5)$ \\
\hline Rahim ağzı kanserini tarama amacıyla yapılan HPV tarama testini duydunuz mu? & $163(\% 52,1)$ & $150(\% 47,9)$ \\
\hline Rahim ağzı kanserini tarama amacıyla yapılan smear testini (Pap-smear testi) duydunuz mu? & $265(\% 84,7)$ & $48(\% 15,3)$ \\
\hline
\end{tabular}

Pap-smear ve HPV testleri ile ilgili bilgi düzeyleri ile ASM'de serviks kanseri taraması yapıldığını bilme durumunun demografik değişkenlerle karşılaştırılması ise Tablo 3 'te gösterilmektedir. Eğitim düzeyi arttıkça HPV testini testini duymuş olma sıklığı artmaktadır $(\mathrm{p}<0,001)$. Aynı şekilde eğitim düzeyi arttıķ̧a Pap-smear testini duymuş olmak da artmaktadır $(\mathrm{p}=0,001)$. ASM'de tarama yapıldığını bilme durumları ise eğitim düzeyi arttıkça azalmaktadır $(\mathrm{p}=0,004)$.

Taramanın ASM'de yapıldığını bilenlere, bu bilgiyi edinme kaynakları sorulduğunda, katılımcıların \%94,5'i doktor/hemşireden, \%4,4'ü komşudan, $\% 0,49$ 'u internetten ve $\% 0,49$ 'u kamu spotlarından öğrendiğini ifade etti.
Katılımcılara rahim ağzı kanseri ve tarama testleri hakkında ayrıntılı bilgi verildikten sonra, katılımcıları bu testi yaptırmaları için ASM'ye davet ettik. \%70,3'ü "evet en kısa zamanda yaptırmak istiyorum derken”, \%29,7'si "hayır yaptırmak istemiyorum" cevabını verdi. Katılımcıların serviks kanseri taramasını yaptırmayı kabul etmeleri ile eğitim düzeyi arasında istatistiksel anlamlı bir fark $\operatorname{vard1}(\mathrm{p}=0,009)$. Sonuçlar Şekil 1'de gösterilmektedir.

\begin{tabular}{|c|c|c|c|c|c|c|c|c|c|}
\hline \multirow[b]{2}{*}{$\mathrm{N}=313$} & \multicolumn{3}{|c|}{$\begin{array}{l}\text { HPV tarama testini duymuş } \\
\text { olmak }\end{array}$} & \multicolumn{3}{|c|}{$\begin{array}{l}\text { Pap-smear testini duymuş } \\
\text { olmak }\end{array}$} & \multicolumn{3}{|c|}{$\begin{array}{c}\text { ASM'de tarama yapıldığını } \\
\text { bilme durumu }\end{array}$} \\
\hline & Evet & Hayır & $\mathrm{p}$ & Evet & Hayır & $\mathrm{p}$ & Biliyor & Bilmiyor & $\mathrm{p}$ \\
\hline \multicolumn{10}{|l|}{ Öğrenim Durumu* } \\
\hline Okuryazar değil & $0(\% 0)$ & $16(\% 100)$ & \multirow{4}{*}{$<0,001$} & $9(\% 56,3)$ & $7(\% 43,8)$ & \multirow{4}{*}{0,001} & $\begin{array}{c}5 \\
(\% 31,3)\end{array}$ & $\begin{array}{c}11 \\
(\% 68,8)\end{array}$ & \multirow{4}{*}{0,004} \\
\hline İlköğretim & $\begin{array}{c}93 \\
(\% 44,9)\end{array}$ & $\begin{array}{c}114 \\
(\% 55,1)\end{array}$ & & $\begin{array}{c}171 \\
(\% 82,6)\end{array}$ & $36(\% 17,4)$ & & $\begin{array}{c}135 \\
(\% 65,2)\end{array}$ & $\begin{array}{c}72 \\
(\% 34,8)\end{array}$ & \\
\hline Lise & $\begin{array}{c}62 \\
(\% 76,5) \\
\end{array}$ & $19(\% 23,5)$ & & $76(\% 93,8)$ & $5(\% 6,2)$ & & $\begin{array}{c}58 \\
(\% 71,6) \\
\end{array}$ & $\begin{array}{c}23 \\
(\% 28,4) \\
\end{array}$ & \\
\hline Üniversite & $8(\% 88,9)$ & $1(\% 11,1)$ & & $9(\% 100)$ & $0(\% 0)$ & & $\begin{array}{c}3 \\
(\% 33,3)\end{array}$ & $6(\% 66,7)$ & \\
\hline Yaş*** & $41,6 \pm 8,9$ & $48,4 \pm 10,3$ & $<0,001$ & $43,9 \pm 9,9$ & $49,9 \pm 10,9$ & $<0,001$ & $43,8 \pm 9,9$ & $46,6 \pm 10,5$ & 0,027 \\
\hline \multicolumn{10}{|l|}{ Medeni Durumu* } \\
\hline Evli & $\begin{array}{c}157 \\
(\% 54,3) \\
\end{array}$ & $\begin{array}{c}132 \\
(\% 45,7) \\
\end{array}$ & \multirow{2}{*}{0,006} & $\begin{array}{c}249 \\
(\% 86,2) \\
\end{array}$ & $40(\% 13,8)$ & \multirow{2}{*}{0,011} & $\begin{array}{c}192 \\
(\% 95,5) \\
\end{array}$ & $\begin{array}{c}97 \\
(\% 86,6) \\
\end{array}$ & \multirow{2}{*}{0,005} \\
\hline Evli değil & $6(\% 25)$ & $18(\% 75)$ & & $16(\% 66,7)$ & $8(\% 33,3)$ & & $9(\% 4,5)$ & $\begin{array}{c}15 \\
(\% 13,4)\end{array}$ & \\
\hline
\end{tabular}

*Ki-Kare testi **Mann-Whitney U testi 
ASM'de serviks kanseri taramasinı yaptırmayı kabul etme oranı

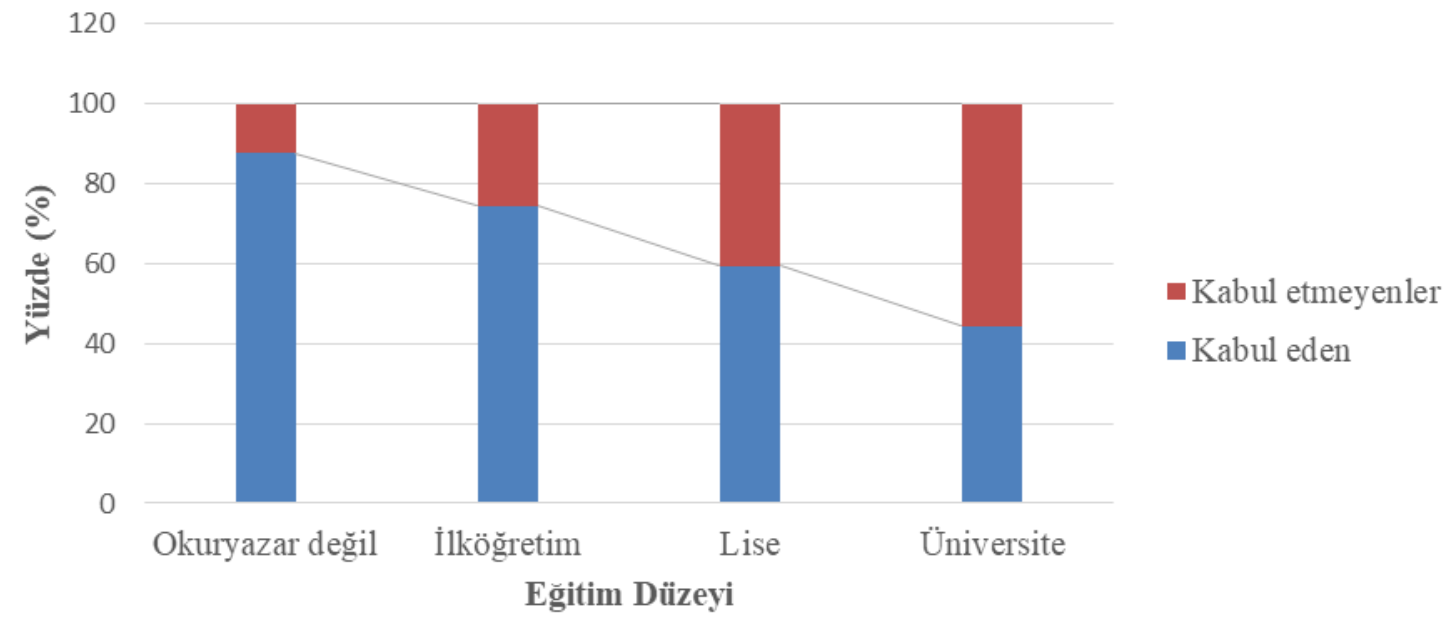

Şekil 1. Aile Sağlı̆̆ı Merkezinde serviks kanseri tarama testi yaptırmayı kabul etme durumu ile eğitim düzeyinin karşılaştırılması

ASM'de tarama yaptırmak istemeyenlere sebepleri sorulduğunda \%52,6's1 jinekolojik muayeneden çekindiğini, \%35,4'ü kadın hastalıkları ve doğum uzmanı tarafından takip edildiğini ve ASM'de yaptırmak istemediğini, \%11,8'i ise rahim ağzı kanseri taramasını gereksiz bulduğu için yaptırmak istemediğini ifade etti. Testi yaptırmama sebebi olarak kadın hastalıkları ve doğum uzmanı tarafından takip edildiğini belirtenlerde eğitim düzeyleri arasında istatistiksel olarak anlamlı bir fark vard $1 \quad(\mathrm{p}<0,000)$. Üniversite mezunlarının $\% 44,4$ 'ü, lise mezunlarının \%22,2'si, ilköğretim mezunlarının ise \%5,3'ü kadın hastalıkları ve doğum uzmanı tarafından takip edildiğini ve ASM'de yaptırmak istemediğini belirtti. Okuryazar olmayanlarda sadece 1 kişi testi yaptırmayı reddetti ve sebep olarak jinekolojik muayeneden çekindiğini ifade etti.

\section{TARTISMA}

Türkiye'de 2004 yılında sitolojiye dayalı serviks kanseri tarama programı başlatılmıştır. Fakat sitolojiye bağlı tarama programında hedef nüfusun oldukça altında kalarak ortalama 25.000 kadın taramaya alınabilmiştir. ${ }^{6} 2010$ yılında birinci basamak sağlık sistemi değişerek koruyucu sağlık hizmetlerinin ön planda olduğu aile hekimliği uygulamasına geçilmesiyle pek çok tarama programı daha aktif olarak uygulanmaya başlanmıştır. HPV DNA tabanlı serviks kanseri taraması ise 2012 yılında başlatılmıştır. Bu uygulamadan sonra serviks kanseri tarama oranları ilk 14 ay içerisinde 3 kat (ayda ortalama 63,893 kadın) artmış ve artmaya devam etmektedir. Türkiye genelinde Ağustos 2013 ile Ekim 2014 tarihleri arasında 1 milyon civarında kadına serviks kanseri taraması yapılmıştır. ${ }^{9} \mathrm{Bu}$ oran ise 16 milyonluk hedef nüfusun yaklaşık \% $\quad 6,25$ 'ini oluşturmaktadır. 2018 yılında Tekpınar ve arkadaşlarının aile hekimliği polikliniğinde yaptığ 1 çalışmada katılımcıların \%28,01'inin serviks kanseri taraması yaptırdığı tespit edilmiştir. ${ }^{10}$ Uysal ve arkadaşlarının 2009 yılında kadın hastalıkları ve doğum polikliniğinde yaptıkları çalışmada ise katılımcıların \%68,5'inin serviks kanseri taraması yaptırdığ1 bulunmuştur. ${ }^{11} \mathrm{Bu}$ araştırmadaki oranın yüksekliği kadın hastalıkları ve doğum polikliniklerinde herhangi bir sebeple yapılan jinekolojik muayene sırasında kanser taramasının da yapılmasına bağlı olabilir. 2010 yılında Açıkgöz A. ve arkadaşlarının İzmir'de yaptığı çalışmada kadınların \%66'sının Pap-smear testi yaptırdığ 1 saptanmıştır. ${ }^{12} 2012$ yılında Sri Lanka'da 219 sağlık çalışanlarının dahil edildiği bir çalışmada katılımcıların \%26,6's1 serviks kanseri taramas1 yaptırmıştır. ${ }^{13}$ Bizim çalışmamızda ise bu oran literatüre göre daha düşük bulundu ve 511 kişilik hedef nüfusun \%13,9'unun daha önce HPV testi yaptırdığ1 tespit edildi. Bunun en büyük sebebi hastaların servikal kanser taramasını nasıl ve nerede 
yaptıracağını bilmemesidir. Tekpınar ve arkadaşlarının çalışmasında kanser taraması yaptırmak isteyenlerin sayıs1, kanser taramas1 yaptırmış olan katılımcı sayısının tam iki katıyd1. ${ }^{10}$ Yine aynı çalışmada serviks kanseri taraması yaptırmak isteyenlerin eğitimden önce oran1 \%35,2 iken eğitimden sonra bu oran \%73,3 olmuştur. Bizim çalışmamızda da benzer sonuçlar bulunmuş olup bilgi verilmeden önce smear yaptırmamış olan katılımcıların \%70'i bilgi verildikten sonra taramaya gelmeyi kabul etti. Fakat Gültekin ve arkadaşlarının Türkiye'de yaptığı geniş kapsamlı çalışmada tarama testlerine ilk davetten sonra katılım istemi \%36,5 idi. Bu sonuçların farklı çıkmasında en önemli faktör hastayla iletişim ve hastaya anlatım tekniğidir. Gültekin ve arkadaşlarının yaptığı çalışmada mail, mesaj, broşür, telefonla görüşme ve yüz yüze teknikleri kullanılmıştır. Çalışma sonuçlarında telefonla ve yüz yüze görüşülen hasta bilgilendirmelerinde katılım isteğinin \%80-90'a ulaşıldığı belirtilmiştir. ${ }^{15}$ Hastaya bilgiler anlatılırken hastanın sosyo-kültürel seviyesine uygun, kendini rahat hissedebileceği, aklına takılan soruları yöneltebileceği bir ortam hazırlamak hastayı ikna etme açısından çok önemlidir.

Ak M. ve arkadaşlarının 2010 yılında yaptığı çalışmada 139 kadından Pap-smear testini duyanların oranı $\% 46,8$ idi. $^{14}$ Gülten G. ve arkadaşlarının 2012 yılında yaptığı çalışmada kadınların \%72,1'i Pap-smear testini duyduklarını belirtmişlerdir. ${ }^{15}$ Bireylerin çoğu tarama testlerini işitmiş ancak, hangi amaçla yapıldığına dair aydınlanmamışlardır. ${ }^{15}$ Bizim çalışmamızda ise Pap-smear testini duyma oranı literatürden yüksek olup, \%84,7 idi. Fakat HPV testinde ise bu oran $\% 52,1$ 'edüşmektedir. Sağlık çalışanları tarafından hastalara bilgi verirken HPV testi ile Pap-smear testi ayrımının anlatılmadığını düşünmekteyiz. HPV'yi ve testini anlatmak tarama oranlarını artıracağı gibi, bize ikincil bir yarar sağlayabilir. İleride daha da yaygınlaşması beklenen HPV aşıları konusunda hastaları bilgilendirmek daha da kolay olacaktır.

Çalışmamızda katılımcıların \%35,8'i rahim ağzı kanser tarama testlerinin ASM'de yapıldığını bilmediklerini ifade etti. İlginç olan eğitim düzeyi ile taramanın ASM'de yapıldığı bilgisi arasında ters ilişki olmasıydı. Ayrıca eğitim düzeyi yüksek olanlarda bilgilendirme sonrası tarama testlerinin ASM'de uygulanmasını kabul etme oranı daha düşük bulundu. Bunun sebebi eğitim düzeyi yüksek kişilerin ASM'leri aktif kullanmamaları ve tarama için Kadın Hastalıkları ve Doğum Polikliniklerini tercih etmeleri olabilir. Çelik M. ve arkadaşlarının 2019 yılında yaptığı çalışmada da benzer olarak eğitim durumu lise ve üzeri olanların birinci basamakta düzenli sağlık hizmet alımı düşük bulunmuştur. ${ }^{16}$ Benzer olarak Delican O. ve arkadaşlarının 2019 yılında yapmış olduğu çalışmada da öğrenim düzeyi arttıkça ve gelir düzeyi yükseldikçe koruyucu sağlık hizmetlerini birinci basamaktan alanların sayısının azaldığı görülmüştür. ${ }^{17}$

Güney Afrika'da 30 yaş ve üzerindeki 1546 kadın ile yapılan araştırmada katılımcıların \%62'sinin servikal kanserler konusunda yeterli bilgisinin olmadığı, bilgi sahibi olanların da sadece \%51'inin sağlık personeli tarafından bilgilendirildiği sonucuna ulaşılmıştır. ${ }^{18}$ Bizim çalışmamızda da taramanın ASM'de yapıldığını bilenlerin büyük bir kısmı $(\% 94,5)$ bu bilgiyi sağlık personeli tarafından öğrendiğini belirtti. Hedef nüfusa bilginin doğru ve uygun bir şekilde sağlık personelleri tarafından anlatılmasının önemi bir kez daha öne çıkmaktadır.

Nilaweera ve arkadaşlarının Sri Lanka'da sağlık personeline yaptığı çalışmada serviks kanseri taraması yaptırmama sebepleri ise gerek görmeme, korkma ve jinekolojik bir şikâyetlerinin olmaması idi. ${ }^{13}$ Eke ve arkadaşlarının 2013 yılında 141 kadın hekime yaptığı çalışmada tarama yaptırmama nedeni en sık; "herhangi bir yakınması olmadığ için gereksinim duymamak”, “jinekolojik muayeneden çekinmek" ve "kendini risk altında görmemek" olarak tespit edilmiştir. ${ }^{19}$ Bizim çalışmamızda ise katılımcıların \%29,7'si kanser taraması hakkında gerekli bilgiler verildikten sonra bile taramayı ASM'de yaptırmak istemedi. Tarama yaptırmak istemeyenlere sebebi sorulduğunda yaklaşık yarısı jinekolojik muayeneden çekindiğini, yaklaşık üçte biri de kadın hastalıkları ve doğum uzmanı tarafından takip edildiğini ve ASM'de tarama yaptırmaya gerek olmadığını ifade etti.

\section{SONUÇ}

Katılımcıların yaklaşık üçte biri ASM'de servikal kanser taramasının yapıldığını bilmiyordu. Çalışma öncesi servikal kanser taraması yaptıran kadınların oranı çok düşük bulunmuş olup gerekli bilgilendirmeler yapıldıktan sonra testi ASM'de yaptırmak isteyenlerin oranı yükselmiştir. 
Hastaların bilgilendirilmesi katılım oranlarını artıran en önemli faktörlerden biridir. Bilgilendirmeye rağmen ASM'de taramayı yaptırmayı kabul etmeyen katılımcıların büyük bir kısmı jinekolojik muayeneden çekindiğini, yaklaşık 3'te biri de kanser tarama takibini Kadın Hastalıkları ve Doğum Polikliniğinde yaptırmak istediğini belirtti. İkinci basamakta bulunan Kadın Doğum Poliklinikleri ile Aile Sağlığı merkezleri, kanser taramaları konusunda entegre bir şekilde çalışmaya başlarsa taramalar daha düzenli yapılabilir ve oranlar artabilir. Hastalara sağlık konusunda bilgi vermek, toplumun sağlığının gelişmesini etkileyen çok önemli bir faktördür. Türkiye'de kanser taraması birinci basamağın görevi olarak görülmektedir. Aile hekimliğinin kanser taramasındaki önemi tartışılmazdır. Fakat toplumun az bir kesimi de tüm bilgilendirmemize rağmen tarama işlemini kabul etmemektedir. $\mathrm{Bu}$ bağlamda bütün sorumluluk hekime yüklenmemelidir. İleride kanser taramaları performansa dahil hizmetler arasında planlanacak olursa, hastaya da sorumluluk verilmesi gerekmektedir.

\section{KAYNAKLAR}

1. Zhang X, Zhao G, Bi H, Zhou M, Wang X, Juan, J. Exploring an appropriatemethod of cervica lcancer screening in rural China. Asia Pacific Journal of PublicHealth2019;31(7):652-8. doi:1010539519876411.

2. Bray F, Ferlay J, Soerjomataram I, Siegel L, Torre A, Jemal A. Global cancerstatistics 2018: GLOBOCAN estimates of incidenceandmortalityworldwidefor 36 cancers in 185 countries. CA: A Cancer Journal for Clinicians 2018;68(6):394-424.

3. Başara B, Çağlar İ, Aygün A, Özdemir T, Morbidite, T.C. Sağlı Bakanlığı Sağlık İstatistikleri Yıllığı 2017. 1. Bask1. Ankara: Kuban Matbaacılık Yayıncılık; 2018. p.40-1.

4. WONCA. Akademik Açıdan Gözden Geçirme Ve İrdeleme: Çekirdek Yeterlikler. 1Başak $\mathrm{O}$, çev. editörü. Aile Hekimliği Genel Pratisyenlik Avrupa Tanımı; 2002. p.49-51.

5. T.C Sağlık Bakanlığı Halk Sağlığı Genel Müdürlüğü Kanser Daire Başkanlığı. Ulusal Hpv-
Smear Tarama Testi Nasıl Yapılır Bilgilendirme. https://hpvtarama.saglik.gov.tr/duyurular/Sayfa/Hp vTaramaTestiNasilYapilir. Erişim tarihi:03.03.2020

6. Ceyhan M. Human papilloma virüs (HPV) aşıları. Klinik Gelişim Dergisi 2012;25:36-9.

7. Gültekin M, Akgül B. HPV screening in islamiccountries. TheLancetInfectiousDiseases 2017;17(4):368.

8. Maver P. J, Poljak M. Primary HPV-based cervical cancer screening in Europe: implementation status, challenges, and future plans. Clinical Microbiology and Infection 2019.

doi: https://doi.org/10.1016/j.cmi.2019.09.006

9. Gultekin M, Zayifoglu Karaca M, Kucukyildiz I, Dundar S, Boztas G, Semra Turan $\mathrm{H}$, Sencan I.Initialresults of population based cervical cancer screening program using HPV testing in one million Turkish women. International Journal of Cancer 2018;142(9):1952-1958.

10. Tekpınar H, Özen M, Aşık Z. Aile Hekimliği Polikliniğine başvuran hastaların kanser taramalarına ilişkin yaklaşımlarının değerlendirilmesi. Türkiye Aile Hekimliği Dergisi 2018;22(1):28-36.

11. Uysal A, Birsel A. Knowledge about cervical cancer risk factors and screening behaviour in Turkey. Asian Pacific Journal of Cancer Prevention 2009;10:345-50.

12. Açıkgöz A, Çehreli R, Ellidokuz H. Kadınların kanser konusunda bilgi ve tutumları ile erken tanı yöntemlerine yönelik davranışları. Dokuz Eylül Üniversitesi Tıp Fakültesi Dergisi. 2011;25(3):145-54

13. Nilaweera R, PereraS, Paranagama N, Anushyanthan A. Knowledge andpractices on breast and cervical cancer screening methods among female health care workers: a Sri Lankan experience. Asian Pacific Journal of Cancer Prevention 2012;13(4):1193-6.

14. Ak M,Canbal M, Turan S, Gürbüz N. Aile hekimliği polikliniğine başvuran kadınlarda papsmear testinin farkındalığının değerlendirilmesi. Konuralp Tip Dergisi 2010;2(2):1-4.

Küçükceran et al., TJFMPC www.tjfmpc.gen.tr 2020; 14(2) 
15. Gulten G, Memnun S, Ayse K, Aygul A, Gulcin A. Breast, cervical, and colorecta lcancer screening status of a group of Turkish women. Asian Pacific Journal of Cancer Prevention 2012;13(9):4273-9.

16. Çelik M, Limnili G, Güldal A. Birinci basamak sağlık hizmetlerinin değerlendirilmesi, The Journal of Turkish Family Physician 2019;10(4):163-72.

17. Delican O, Yapakçı A, Yılmaz E, Altun A, Kesen C, Atal S, Ailelerin Aile Hekimliği'nden hizmet alımı ve memnuniyeti, The Journal of Turkish Family Physician 2019;10(1):18-34.

18. Ramathuba DU, Ngambi D, Khoza LB, Ramakuela NJ. Knowledge, attitudes and practices regarding cervical cancer prevention at Thulamela Municipality of Vhembe District in Limpopo Province. African Journal of Primary Health Care\&Family Medicine 2016;8(2):1-7.

19. Nur Eke R, Atsız Sezik H, Özen M. Serviks kanseri; kadın hekimler yeterince farkında mı?. Tepecik Eğitim ve Araştırma Hastanesi Dergisi 2016;26(1):53-7. 